\title{
Dosage Forms Mentioned in Kashyapa Samhita - A Review
}

\author{
Review Article
}

\section{Sahara Shrestha ${ }^{1^{*}}$, Prashant Bedarkar ${ }^{2}$, Chaudhari Swapnil $\mathbf{Y}^{2}$, Galib $\mathbf{R}^{3}$, Patgiri BJ ${ }^{4}$, Prajapati Pradeep $\mathbf{K}^{5}$}

\begin{abstract}
1. Post-Graduate Scholar, 2. Assistant Professor, 4. Professor and Head
Department of Rasashastra \& Bhaishajya Kalpana, I.P.G.T. \& R.A., Gujarat Ayurved University, Jamnagar

3. Associate Professor, 5. Professor, Department of Rasashastra \& Bhaishajya Kalpana, AIIA, New Delhi
\end{abstract}

\begin{abstract}
Kashyapa Samhita is an Ayurvedic treatise having main focus on the health and well-being of children and their pathological manifestations. It describes Mantras (Vedic Hymns), Sutikagarogas (diseases of puerperal period), Dhatri (midwife), Dantodbhava (dentition) etc., which has its sole theme devoted to the vicinity of paediatrics. Different dosage forms or medicaments have been depicted in this ancient wisdom of knowledge especially for paediatric diseases. A wide array of herbs, minerals and metals has been used throughout the text. Total 670 formulations mentioned in the classics were screened and formulated into different dosage forms like Swarasa, Kalka, Kwatha, Hima, Sneha, Avaleha, Arista, Asava, Dhoopana, Anjana etc. Various Upa kalpanas like Yavagu, Ksheera, Kambalika etc. also have been amalgamated sporadically in this Samhita. Most of the formulations for internal administration have been advised to administer along with Ghrita and / or honey. In the current review, an attempt has been made to highlight the uniqueness of such formulations and to bring forward the specialities of such formulations with rational behind using these formulations.
\end{abstract}

Keywords: Kalpana, Kashyapa, Kaumara, Raksha Vidhi, Upakalpana

\section{Introduction}

The treasure of Ayurveda lies in the literature that has been the epitome of the perseverance of our ancient seers. Most of these treatises are found only in parts while some others are yet to be discovered. One such book that although is available as a Vilupta Tantra (Extinct literature) has a lot to offer is Kashyapa Samhita. It is the foremost book that has main theme focused on the vicinity of a healthy progeny, proper growth of children, their diseases and nurturing the mother. The text consists of a lot of chapters dealing with promoting health, preventing epidemics and curing diseases especially for paediatrics. It has descriptions of innovative concepts of Mantras (Vedic Hymns), Sutikagarogas (diseases of puerperal period), Dhatri (midwife), Dantodbhava (dentition) etc. that deals with paediatrics. In the context of Ayurveda, any substance can be called as "Bheshaja" as it can mitigate the symptoms, chronicity or even complications of a disease. It is also called as "Aushadham" meaning a substance having the capability to alleviate the pain. Kalpana means 'Yojana' (planning) i.e. the skill of making use of even a single Dravya (substance) or different Dravyas with their permutation and combinations to bring a final optimized product. It is the basic concept of rational drug designing keeping in

\section{*Corresponding Author:}

\section{Sahara Shreshta}

MD Scholar, Dept. of Rasashastra \& Bhaishajya

Kalpana, I.P.G.T. \& R.A.,

Gujarat Ayurved University, Jamnagar-361008

Email id: saharestha@yahoo.com mind the safety \& efficacy of the medicament. A lot of Kalpanas or formulations have been depicted in this ancient wisdom for paediatrics. It has mentioned Saptavidha Kashaya Kalpanas (Churna, Sheeta Kashaya, Swarasa, Abhisava, Phanta, Kalka and Kwatha) as its primary formulations according to difference in disease and age. A lot of secondary formulations have also been described in Kashyapa Samhita. Wide arrays of herbs, minerals and metals have been used throughout the text. Various Upakalpanas like Yavagu, Ksheera, Kambalika etc. also have been amalgamated sporadically in this Samhita. Some of the innovative mentioned formulas have added new dimensions in the field of Bhaishajya Kalpana. In the current review, an attempt has been carried out to highlight the uniqueness of such formulations in Kashyapa Samhita and to bring forward the specialities of such formulations with rational behind using these formulations.

\section{Materials and methods}

Kashyapa Samhita was screened thoroughly to compile all the formulations described in this classic. The formulations were further categorized into different dosage forms so as to classify the formulations into different groups. Total 670 formulations are screened and complied but formulations with parts of Shlokas missing have not been included in this list. [Table 1] Total 43 different dosage forms have been mentioned in the Samhita. The terms have been used as mentioned in the text to denote the formulations as far as applicable. The most frequently used Anupanas were also sorted. The role of Kashyapa Samhita in addition of different dosage forms in the field of Bhaishajya Kalpana was also assessed in present review. 


\section{Results and Discussion}

Acharya Kashyapa has given equal importance to Aahara Kalpana along with A ushadha Kalpana as treatment modality. The Samhita has mentioned formulations using different Aahara Dravyas. Aahara kalpana has also been said as Maha Bheshaja. Congenial food (A ahara Vikalpa) and its effect have been described thoroughly. Maximum formulations have been mentioned in the chapter Antarvatni chikitsa. Acharya Kashyapa has mentioned the drug dosage according to the age of children. Medicaments advised for external applications have higher frequencies throughout the text as these dosage forms are more convenient for children. Kwatha (decoction) dosage forms are mostly used for Parisechana (irrigation) and Avagahana (tub bath). Churna (powdered drug) has also been mentioned for Avachurnana (dusting powder). It can be justified by the fact that external dosage forms are easier and more appropriate for paediatric manifestations due to their advantages like easy for application, quick absorption etc.

In context of Saptavidha Kashaya Kalpana, Acharya Kashyapa is the first person who mentioned use of Antarikshaambu (rain water) in the preparation of Kashaya Kalpana. Kashyapa has even mentioned about molasses in Phanta. This is praised in patients with less strength of Doshas, for children and minor diseases. (1)

Swarasa is mentioned in lesser number in this treatise as it is difficult to digest in nature and useful in patients having strong Agni. Swarasa is the essence of plant and is highly concentrated. Most of the plants have bitter taste with lesser palatability which may induce vomiting as well. Kaumaras, Sutikas and Dhatris are Sukumara (weak / convalescent) patients. Hence Swarasa may have been mentioned in lesser number of times in the classic.

The dose of Ghrita to be administered in children right from birth has also been described. Along with this, dose of oleaginous substances for emesis and purgation have been also mentioned. The internal medicaments like Leha, Avaleha, Ksheerapaka and Aushadha Kalpanas have been designed in such ways to facilitate its solubility and increase its nutrient values. Most of the internal formulations are to be administered in the form of lickables for convenience to children. Oral formulations have been predominantly advised to be administered with Madhu and Ghrita as Anupana. When Ghrita and Madhu mixed in equal quantity is administered, it acts as poison in body. (2) But when it is administered in smaller doses for long duration, makes the body adoptable, is called Satmya. (3) This is a method to strengthen the immunity of the children. Honey is reported to possess antiseptic, antimicrobial, antipyretic, anti-inflammatory, antiallergenic, antioxidant, healing and cleansing and blood-purifying actions. It promotes rehydration, stimulates immunity and beneficial for all types of skin diseases. (4) Honey is one of the best examples of Yogavahi Drayas. They are used to enhance the bioavailability, tissue distribution, and efficacy of drugs, especially the ones with poor oral bioavailability and decrease the adverse effects. (5) So, honey may have been used repeatedly as an Anupana to boost immunity and for its easy metabolism.

Tandulodaka has also been frequently mentioned to be taken as Anupana. Suramanda is mostly used for Anjanavarti preparation. The probiotic bacteria are mainly found in fermented foods, and dairy products, which play a predominant role as carriers of various other health benefits. These foods are well suited for promoting the positive health image of probiotics for several reasons. (6) Clinical trials have demonstrated that probiotics may decrease the incidence of respiratory-tract infections and dental caries in children. (7), (8). Tandulodaka, Asava, Arista including Suramanda are likely to be enriched with these probiotic bacteria that help to strengthen the health and maintain the flora of useful bacteria in the body.

Acharya Kashyapa stated that healthy and unhealthy condition depends on Lehana. (9) Kashyapa has highlighted that the use of gold in the context of Swarna Prashana Samskara to neonates is to increase immunity. (10) Modern research shows that gold particles have anti-oxidant property and $\mathrm{T}-$ lymphocyte activation and thus involve in regulation of antigen specific immune response. (11) In another study, colloidal gold was found to improve cognitive functioning, which was measured by IQ scores. (12) Gold is already proven for its immnomodulatory effects because of its antibacterial action against different organisms but when it is mixed with Madhu and Ghrita it widens its spectrum of action to stimulate body immune cells. (13)

Ksheera (breast milk), its formation and significance have been incorporated in the text. Breast milk provides all the nutritional requirements for the rapidly growing infant and contains a variety of protective factors, such as immunoglobulin (Ig) A, immuno-competent cells, fatty acids, oligosaccharides, lysozyme or lactoferrin, that protect breast-fed infants against infectious diseases. (14), (15), (16), (17). Commensal bacteria usually present in breast milk of healthy mothers, such as lactobacilli, lactococci, enterococci and leuconostoc spp., can also be considered as key elements of the defence system that this biological fluid offers to the infant. (18), (19), (20). Some of the lactic acid bacteria strains with such origin have already been shown to possess probiotic properties, including the inhibition of a wide spectrum of infant pathogenic bacteria by competitive exclusion and / or through the production of antimicrobial compounds, such as bacteriocins, organic acids or hydrogen peroxide. (21), (22), (23).

Metals, minerals and their compounds have been frequently used in Leha, Churna, Lepa, Anjana 
and preparation of vessels. The properties of Lauha (Iron) like 'Sarvavyadhiharam' (ability to cure all the diseases) and 'Rasayanavaram' (best among all the rejuvinating drugs) show the superiority of this metal in therapeutics. (24) Iron-deficient children are mainly inattentive and distractible and suffer from learning disabilities, a finding consistent with the role of iron deficiency in cognitive deficits and mental retardation. (25) A causal relationship between iron deficiency and poor cognitive development and/or behavioral problems has been well-established over the past 3 decades. (26), (27), (28), (29), (30). This may be the reason behind ample use of iron and iron compounds in the text. Kashyapa has even mentioned about the specificity of vessels to be used for drug formulation. Swarna, Shankhanabhi, Madhu, Ghrita and breast milk is to be rubbed in a Kamsya (bronze) vessel for Akshipurana. (31) Therapeutic use of Tamra (Copper) in eye diseases is also accepted by Rasashastra texts. (32) Published reports proved that copper surfaces completely killed bacteria. $E$. coli inoculated on to copper coupons by membrane damage. (33)

Mina Taila is first time mentioned in the text along with other Sneha Kalpanas which is good in diseases due to vitiation of Vata. (34) Fish oil contains omega-3 fatty acids eicosapentaenoic acid (EPA) and docosahexaenoic acid (DHA), precursors of certain eicosanoids that are known to reduce inflammation in the body. (35), (36). Recent studies also reported significant improvement in joint tenderness and swelling in patients with rheumatoid arthritis after receiving fish oil supplements for a period of 24 weeks. (37) Mrigrajavasa (fat of lion) and Panchabhautika Taila have been mentioned for Nasya (nasal instillation) in Vishama Jwara and Panchaindriya vivardhanama (to increase the power of all five sensory organs) respectively. (38), (39).

Acharya Kashyapa has laid immense emphasis on the Raksha Vidhi. It is a technique to ward off evil Rakshas or micro-organisms. A whole chapter has given emphasize on describing Dhoopana Dravyas (drugs used for fumigation). Dhoopana has broad spectrum of aesthetic, psychological and medical significance. Dravyas like Samghati (a piece of monk's rob), slough of snake, faeces and feathers of cock and Ghrita have been mentioned for fumigation in the treatment of Putana. (40) Likewise, various herbs, animal products and even gems in the form of Dharana Dravyas have been advised to be hung on different parts of the body and even in different parts of the room. Amulets of plants like Varuna, Putranjivaka, Chitraka, animal parts like tongue of snake, chasa etc. have been advised in treatment of various diseases. Mineral compounds of sulphur like Haritala (Arsenic trisulphide), Manashila (Arsenic disulphide) and animal products like hair, nails, horns etc. have been used where keratin is a structural component which contains sulphur. This sulphur content might play a key role in the disinfection.
Mantras have been profoundly used in the text. Mantras are referred to by people as energy based sounds which fabricate physical vibrations in the human body which thereby produces energy waves within one's body. The powerful sounds of mantra create energy which helps to heal faster from any pathology. (41) The use of Mantras may have been a technique of soothing \& pacifying the children and invoking a better ambience. The Sam hita has different formulations that comprise of carbon compounds. Application of Mashi prepared with Antardhuma process has been mentioned for increasing size of ear lobe. (42) Ghrita for increasing ear lobe has been mentioned but the Shloka is incomplete. For Shyawathu (swelling), ash of Palasha as a single drug mixed with cow's urine should be anointed over localised area. (43) Palasha Kshara, a reputed preparation of Ayurveda, is valued for the therapeutic properties like anthelmintic antiimplantation, antiovulatory, abortificient, antileprotic, antigout, antiestrigenic, spasmogenic, antifungal, antispasmodic, hypotensive, astringent, alterative, aphrodisiac, antiasthmatic, and bactericidal. (44)

Acharya Kashyapa has even advised showing the sun to the newly born child during the first month itself. (45) UV-B fraction of sunlight is helpful in the synthesis of vitamin D. Infants who are breastfed but do not receive supplemental vitamin $\mathrm{D}$ or adequate sunlight exposure are at increased risk of developing vitamin D deficiency or rickets. (46), (47), (48), (49). The exposure to the sunlight is a way to help in the activation of vitamin $\mathrm{D}$ synthesis to the growing infant.

\section{Conclusion}

Kashyapa Samhita is only one available treatise in Ayurveda emphasized on complete care of children and formulations therapeutically used in treatment of various pathological manifestations of paediatrics. The screening of formulations through Kashyapa Samhita reveals significant therapeutic attributes in Ayurvedic medical science for both internal administration and external application. Majority of doses forms mentioned are for external applications. The internal formulations have been advised to be administered with bioenhancers and probiotics. Raksha Vidhi has immense significance with the usage of drugs having antibacterial effects. The text itself is an efficient source of various medicaments for establishing the health and maintaining proper growth and development of children by both food supplements and medicine. Number of innovative formulations like Mrigaraja Nasya, Mina Taila, Mashi have been mentioned in it. This work is anticipated to be convenient for referring the formulations and different dosage forms emphasized in Kashyapa Samhita and reduce the sternous efforts of researchers to gather information. This also emphasizes the frequency of dosage forms used in different pathological conditions. 
Table 1: Categorization of formulations in Kashyapa Samhita

\begin{tabular}{|c|c|c|}
\hline Sr. No. & Formulation & Frequency \\
\hline 1 & Kwatha & 141 \\
\hline 2 & Lepa & 72 \\
\hline 3 & Kalka & 59 \\
\hline 4 & Churna & 44 \\
\hline 5 & Ghrita & 42 \\
\hline 6 & Yusha & 42 \\
\hline 7 & Taila & 40 \\
\hline 8 & Dhoopa & 38 \\
\hline 9 & Lehana & 36 \\
\hline 10 & Yavagu & 29 \\
\hline 11 & Avaleha & 20 \\
\hline 12 & Swarasa & 18 \\
\hline 13 & Ksheera Paka & 15 \\
\hline 14 & Mamsa Rasa & 11 \\
\hline 15 & Peya & 7 \\
\hline 16 & Rasakriya & 6 \\
\hline 17 & Varti & 6 \\
\hline 18 & Dharana & 6 \\
\hline 19 & Goli & 6 \\
\hline 20 & Panaka & 5 \\
\hline 21 & Mashi & 2 \\
\hline 22 & Kambalika & 2 \\
\hline 23 & Guti & 2 \\
\hline 24 & Upanaha & 2 \\
\hline 25 & Abhisava & 1 \\
\hline 26 & Arista & 1 \\
\hline 27 & Madha & 1 \\
\hline 28 & Asava & 1 \\
\hline 29 & Sandhana & 1 \\
\hline 30 & Modaka & 1 \\
\hline 31 & Lasuna Kalpa & 1 \\
\hline 32 & Shadava & 1 \\
\hline 33 & Upodika & 1 \\
\hline 34 & Odana & 1 \\
\hline 35 & Vilepi & 1 \\
\hline 36 & Manda & 1 \\
\hline 37 & Khada & 1 \\
\hline 38 & Apupa & 1 \\
\hline 39 & Veshvara & 1 \\
\hline 40 & Hima & 1 \\
\hline 41 & Kshara & 1 \\
\hline 42 & Phalavarti & 1 \\
\hline \multirow[t]{2}{*}{43} & Vasa (Nasyartha) & 1 \\
\hline & Total Formulations & 670 \\
\hline
\end{tabular}

\section{References}

1. Marich Kashyapa, Tiwari P. V. editor. Kashyapa Samhita Khila Sthana, Bhaisajyopakramaniya Adhyaya, 3/40. Revised Edition. Varanasi; Chaukhamba Vishvabharti; 2008. 454 p.

2. Agnivesha, Charaka Samhita, Charaka Chandrika Hindi Commentary by Dr.Brahmananda Tripathi,
Sutrasthana 26/90. Reprint Edition. Varanasi; Chaukhamba Surbharati Prakashana; 2009. 497 p.

3. Agnivesha, Charaka Samhita, Charaka Chandrika Hindi Commentary by Dr.Brahmananda Tripathi, Vimanasthana 8/118. Reprint Edition. Varanasi; Chaukhamba Surbharati Prakashana; 2009. 769 p.

4. Needham AW. Health benefits of honey, 2008. Available from: http://www.bees-online.com/Health Benefits Of Honey. htm.

5. Randhawa GK, Kullar JS. Bioenhancers from mother nature and their applicability in modern medicine. Int J App Basic Med Res 2011; 1: 5-10.

6. Heller KJ. Probiotic bacteria in fermented foods: Product characteristics and starter organisms. Am J Clin Nutr 2001; 73: 374-379.

7. Hatakka K, Savilahti E, Ponka A, Meurman JH, Poussa T, Nase L et al. Effect of long term consumption of probiotic milk on infections in children attending day care centres: double blind, randomised trial. BMJ 2001; 322 (7298): 1327.

8. Hatakka K, Savilahti E, Ponka A, Meurman JH, Poussa T, Nase L et al. Effect of long term consumption of probiotic milk on infections in children attending day care centres: double blind, randomised trial. BMJ 2001; 322 (7298): 1327.

9. Marich Kashyapa, Tiwari P. V. editor. Kashyapa Samhita Sutra Sthana, Lehana Adhyaya, 18/4. Reprint Edition. Varanasi; Chaukhamba Vishvabharti; 2008. 3 p.

10. Marich Kashyapa, Tiwari P. V. editor. Kashyapa Samhita Sutra Sthana, Lehana Adhyaya, 18/26. Reprint Edition. Varanasi; Chaukhamba Vishvabharti; 2008. 7 p.

11. Villiers C, Freitas H, Couderc R, Villiers M and Marche P. Analysis of the toxicity of gold nano particles on the immune system: effect on dendritic cell functions. J Nanopart Res 2010; 12(1): 55-60.

12. Abraham GE, McReynolds SA, Dill JS. Effect of colloidal metallic gold on cognitive functions: A pilot study. Frontier Perspect 1998; 7:39-41.

13. http://infoayushdarpan.blogspot.in/201 1/05/swarna -bindu-prashana.html

14. Newburg DS. Innate immunity and human milk. J Nutr 2005; 135: 1303-1312

15. Wright KC, Bauer M, Naylor A, Sutcliffe E and Clark L. Increasing breastfeeding rates to reduce infant illness at the community level. Pediatrics 1998; 101: 837-844.

16. Hanson, LA and Korotkova M. The role of breastfeeding in prevention of neonatal infection. Semin Neona-tol 2002; 7: 275-281.

17. Morrow AL and Rangel JM. Human milk protection against infectious diarrhea: implications for prevention and clinical care. Semin Pediatr Infect Dis 2004; 15: 221-228.

18. Matsumiya $\mathrm{Y}$, Kato N, Watanabe $\mathrm{K}$ and Kato $\mathrm{H}$. Molecular epidemiological study of vertical transmission of vaginal Lactobacillus species from mothers to newborn infants in Japanese, by arbitrarily primed polymerase chain reaction. J Infect Chemother 2002; 8: 43-49.

19. Heikkila M and Saris P. Inhibition of Staphylo- 
coccus aureus by the commensal bacteria of human milk. J Appl Microbiol 2003; 95: 471-478.

20. Martin R, Langa S, Reviriego C, Jimenez E, Xaus J, Fernandez L et al. Human milk is a source of lactic acid bacteria for the infant gut. J Pediatr 2003; 143: $754-758$.

21. Beasley and Saris. Nisin-Producing Lactococcus lactis Strains Isolated from Human Milk. Appl Environ Microbiol 2004; 70(8): 5051-5053.

22. Martin R, Olivares M, Martin M, Fernandez L, Xaus $\mathrm{J}$ and Rodriguez J. Probiotic potential of 3 lactobacilli strains isolated from breast milk. J Hum Lact 2005; 21: 8-17.

23. Vagbhatacharya, Rasa ratna samucchaya, Vijnan bodhini Hindi Commentary by Prof. Dattatreya Anant Kulkarni, 5/136-139. Reprint Edition. New Delhi; Meharchanda Lachamanadas Publication; 2010. 120 p.

24. Halterman JS, Kaczorowski JM, Aligne CA, Auinger P, Szilagyi PG., Iron deficiency and cognitive achievement among school-aged children and adolescents in the United States. Pediatrics 2001; 107(6): 1381- 1386.

25. Mccann JC, Ames BN. An overview of evidence for a causal relation between iron deficiency during development and deficits in cognitive or behavioral function. Am J Clin Nutr 2007; 85: 931-45.

26. Logoff B, De Andraca I, Castillo M, Smith JB, Walter T, Pino P. Behavioral and developmental effects of preventing iron-deficiency anemia in healthy full-term infants. Pediatrics 2003; 112: 84654.

27. Timimi S, Taylor E. ADHD is best understood as a cultural construct. Br J Psychiatry 2004;184:8-9.

28. Lozoff B, Georgieff MK. Iron deficiency and brain development. Semin Pediatr Neurol. 2006;13:15865.

29. Beard JL. Why iron deficiency is important in infant development. J Nutr. 2008;138:2534-6.

30. Marich Kashyapa, Tiwari P. V. editor. Kashyapa Samhita Sutra Sthana, Kalpa Sthan, Shatkalpa, 4/12. Reprint Edition. Varanasi; Chaukhamba Vishvabharti; 2008. 344 p.

31. Vagbhatacharya, Rasaratnasamucchaya, Vijnanbodhini Hindi Commentary by Prof. Dattatreya Anant Kulkarni, 5/46. Reprint Edition. New Delhi; Meharchanda Lachamanadas Publication; 2010. 100 p.

32. Espirito Santo C, Lam EW, Elowsky CG, Quaranta D, Domaille DW, Chang CJ, et al. Bacterial killing by dry metallic surfaces. App Environ Microbiol. 2011;77:794-802.

33. Marich Kashyapa, Tiwari P. V. editor. Kashyapa Samhita Chikitsa Sthana, Dhatri Chikitsa 18/45. Reprint Edition. Varanasi; Chaukhamba Vishvabharti; 2008. 251 p.
34. Moghadasian, Mohammed H. Advances in Dietary Enrichment with N-3 Fatty Acids. Critical Reviews in Food Science and Nutrition 2008; 48 (5): 40210.

35. Cleland L, James M, Proudman S. Fish oil: What the prescriber needs to know. Arthritis Research \& Therapy 2006; 8 (1): 679-8i .

36. Kremer JM. Dietary fish oil and olive oil supplementation in patients with rheumatoid arthritis. Arth and Rheum 1990; 33(6): 810-820.

37. Marich Kashyapa, Tiwari P. V. editor. Kashyapa Samhita, Khila Sthan, Visham Jwara Nirdesha, 1/89. Reprint Edition. Varanasi; Chaukhamba Vishvabharti; 2008. 436 p.

38. Marich Kashyapa, Tiwari P. V. editor. Kashyapa Samhita, Kalpa Sthan, Shatakalpa Adyaya, 4/32. Reprint Edition, Varanasi; Chaukhamba Vishvabharti; 2008. 346 p.

39. Marich Kashyapa, Tiwari P. V. editor. Kashyapa Samhita, Chikitsa Sthan, Balagraha Chikitsa, 4/42. Reprint Edition, Varanasi; Chaukhamba Vishvabharti; 2008. 174 p.

40. Chakraborty S. Prayer and Mantra as a Provenance of healing: a sociological analysis. SRJIS 2015; 3 (21): $1118-1125$.

41. Marich Kashyapa, Tiwari P. V. editor. Kashyapa Samhita, Sutra Sthan, Chudakarana Adhyaya, 21/1. Reprint Edition, Varanasi; Chaukhamba Vishvabharti; 2008. 20 p.

42. Marich Kashyapa, Tiwari P. V. editor. Kashyapa Samhita, Khila Sthan, Shyawathu Chikitsa, 17/77. Reprint Edition, Varanasi; Chaukhamba Vishvabharti; 2008. 647 p.

43. Anonymous. Database on Medicinal Plant Used in Ayurveda. Vol I. New Delhi: CCRAS; 2007. p. 336.

44. Marich Kashyapa, Tiwari P. V. editor. Kashyapa Samhita, Khila Sthan, Jatakarma Adhyaya, 12/3. Reprint Edition, Varanasi; Chaukhamba Vishvabharti; 2008. 595 p.

45. Kreiter S, Schwartz R, Kirkman H, Charlton P, Calikoglu A, Davenport $M$. Nutritional rickets in African American breast-fed infants. J Pediatr 2000;137:153-157.

46. Pugliese MF, Blumberg DL, Hludzinski J, Kay S. Nutritional rickets in suburbia. J Am Coll Nutr 1998; 17:637-641.

47. Sills IN, Skuza KA, Horlick MN, Schwartz MS, Rapaport R. Vitamin D deficiency rickets. Reports of its demise are exaggerated. Clin Pediatr (Phila). 1994; 33: 491-493.

48. Binet A, Kooh SW. Persistence of vitamin Ddeficiency rickets in Toronto in the 1990s. Can J Public Health 1996; 87:227-230.

49. Daaboul J, Sanderson S, Kristensen K, Kitson H. Vitamin D deficiency in pregnant and breast-feeding women and their infants. J Perinatol 1997; 17:10-14. 